\title{
IN OTHER ... ROMANIAN WORDS. PRACTICAL CONSIDERATIONS ON TRANSLATING
}

\author{
Diana V. BURLACU \\ Leipzig University, Germany \\ Babeș-Bolyai University Cluj-Napoca, Romania \\ Romanian Language Institute Bucharest, Romania \\ e-mail: dianav.burlacu@gmail.com
}

\begin{abstract}
The present article evolved from a series of short Romanian translations based on the German version of Adam Fletcher's book entitled "How to be German in 50 new steps/ Wie man Deutscher wird. In 50 neuen Schritten” (2016). Spanning more than three months, the outcomes of the translating process were rendered concrete with the collective contribution of five Erasmus students ${ }^{l}$ at Leipzig University, Germany, all of whom (their teacher included) are native speakers of the Romanian language. Frequently employing a combination of free and formal translation-styles, the team of translators-to-be strove to retain all the meanings, be they propositional or expressive, presupposed or evoked, or those generated by idioms, fixed expressions and non-equivalence in the original text. They provided alternative translations, mostly differing on the levels of lexis, grammar and register, but eventually negotiated the best one, which naturally became the final translated text, as much as possible freed from any traces of "translationese" and suitable for any authentic contemporary sample of Romanian language.
\end{abstract}

Keywords: German; language; meaning; stereotype; translation;

Placed in the range of academic Cinderellas, the field of translation studies has been associated with the inauthentic secondary or, even worse, second-hand activity of a copyist, since the authorship has already been granted to the primary source text. Criticism is far from being completed: a mistletoe-like text growing parasitically on other texts may hardly be looked upon in credibility or earnestness. Simultaneously, the translator would commonly share either the status of an imitator (when their translation mirrors the original, thus triggering the accusation of translationese) or that

\footnotetext{
${ }^{1}$ I am grateful to Patricia Gheorghe and Ramona Băcănaru (Technical University of Civil Engineering of Bucharest), Andreea Tufeanu (University of Bucharest), Denisa Urs and Paula Heredea (University of Oradea), for their major role throughout the whole process of translation and for all their pertinent observations on the source and target texts.
} 
of a traitor, summed up punningly by the famous Italian phrase Traduttore, traditore (when the translated text differs too much from the source text).

Hence the dichotomic nature of translating: on the one hand, the robotlike mechanical representation of a source-language (SL) text into a targetlanguage (TL) text, and on the other hand, the artist-like creative production echoing a remote original text.

Bluntly described, the present study is "a get-your-hands-dirty, wrestlewith-reality type" (Landers, 2001: ix), aiming to draw attention to the practical, applied aspects of the translating process. The primary literature is represented by five informal narrative texts in German, excerpted from Adam Fletcher's bilingual guide How to be German in 50 new steps/ Wie man Deutscher wird. In 50 neuen Schritten, written in English and published in 2016. The diachronical considerations on Translation Studies at the beginning are meant to highlight the essence of literary translations: as opposed to technical or specialized translation, where lexical meanings are of utmost importance, the literary rendering from one language into another highly counts on the semantic and pragmatic meanings, rather than on the accuracy of distinct lexemes. The underlying principles of our approach have closely followed the directions suggested by Clifford E. Landers, in his practical guide entitled Literary Translation (2001):

$\checkmark \quad$ fluency and transparency, the success of a translated text depending "on the degree to which it 'doesn't read like a translation' " (49);

$\checkmark \quad$ the author-translator-reader triangle, the translator being a mediator between languages and cultures. Taking sides with the so-called 'targeteers', as opposed to 'sourcerers' (Newmark, in Landers, 2001: 51), we have striven to provide natural texts in the target language, Romanian, although we were faced, several times, with the "'resistance' of the SL culture and SL language" (Landers, 2001: 52);

$\checkmark \quad$ thought by thought, rather than word by word;

$\checkmark \quad$ preservation of the SL register and tone, the latter referring to "the overall feeling conveyed by an utterance, a passage, or an entire work, including both conscious and unconscious resonance" (68);

$\checkmark \quad$ 'straight' translation, rather than adaptation (out of pedagogical reasons), yet obeying the principle: "provide only as much information as can be conveyed without resort to artificiality" (80).

Chesterman's so-called 'translation supermemes ${ }^{2}$, (2016: 3): sourcetarget (hence the directionality of translation), equivalence (4), untranslatability (6), free-vs-literal (8), as well as the semiotic all-writing-is-

\footnotetext{
${ }^{2}$ Defined as "a unit of cultural transmission" (Dawkins, in Chesterman 2016: 1), the meme is a concept originating in sociobiology and coined by Richard Dawkins, in The Selfish Gene (1976, 1989).
} 
translating (9), roughly mention the same ideas, yet from a rather philosophical perspective.

The study continues with a short description of Fletcher's book and some basic information on the translator into German, Ingo Herzke. Prior to the five translations into Romanian, several semantic problems, cultural concepts and lexical variants resulting from the incongruities between the source language, German, and the target language, Romanian, are debated and clarified, thus ensuring a better comprehension of the translating progress. In order to facilitate the textual access of readers who cannot understand this Romance language, every translation is followed by the respective German version (Annex 1.1, Annex 2.1, Annex 4.1 and Annex 5.1) and the English original (Annex 1.2, Annex 2.2, Annex 3.1, Annex 4.2 and Annex 5.2).

In a plain wide-ranging definition, "translation is an art which requires aptitude, practice, and general knowledge" (in Baker, 1992: 3), yet

"[...] translators will need something other than the current mixture of intuition and practice to enable them to reflect on what they do and how they do it. They will need, above all, to acquire a sound knowledge of the raw material with which they work: to understand what language is and how it comes to function for its users" (Baker, 1992: 4).

Sadly, due to a lack of some or all of these assets, there have recently emerged on the market numerous human translators and machine translation services and programs of shallow and unprofessional nature, too quickly and too easily providing various texts labelled as translationese:

"Translation scholars [...] speak of the language of translation as a separate 'dialect' within a language, which they call third code ... or translationese ... Translationese has been originally described ... as the set of "fingerprints" that one language leaves on another when a text is translated between the two" (Baroni and Bernardini, in Korzen and Gylling, 2012: 29).

Since translating may be as old as the Tower of Babel - a moment in the history of humankind accounting for the emergence of different languages, as narrated in the Book of Genesis, one would have expected a natural improvement in the act of translating, not a regress, as is often the case.

Already in the $1^{\text {st }}$ century BC, Cicero was fully aware of the fact that his translations should, at all times, be adequate to the target language, by 
preserving merely the ideas, not the wording in the source language: "I translate thoughts, their forms or, in other words, their representations, yet in a language suitable to our own usage" (my translation - Cicero, in Stolze, 1994: 15).

Later on, Hieronymus (348-420) would also advocate for free or 'dynamic' translation (Nida, in Jakobsen 1994: 35), as opposed to the socalled faithful, formal or literal translation: "I do not translate word for word, but meaning for meaning" (m.t. - Cicero, in Stolze 1994: 15). More than one thousand years later, Martin Luther (1483-1546) resumed the same declaration: "understand the idea, then the words will follow naturally" (15).

Such a theoretical background has actually supported the present article, which gathers the latest translations realized at Leipzig University, Germany, in the period November 2019 - January 2020, within the GermanRomanian Translation Course, B2-C1 levels, according to the Common European Framework of Reference for Languages (CEFR). Stemmed from the collective work of five Erasmus students and their teacher, all native speakers of the Romanian language, these translations into Romanian have been continually worked upon during the course, as well as after it, in several attempts to provide the 'best' version of the original texts. Closely following the above-mentioned general guidelines, we have tried not to omit or distort the overt or covert meanings, neither to forget the particularities of the target language, as well as the basic rules of writing texts in Romanian.

The primary material was extracted from Adam Fletcher's bilingual work, Wie man Deutscher wird. In 50 neuen Schritten/ How to be German in 50 new steps (2016), published in Munich, by C.H. Beck Publishing House, a sequel to Wie man Deutscher wird. In 50 einfachen Schritten/ How to be German in 50 easy steps (2013). The German version actually represents a translation from English by Ingo Herzke ${ }^{3}$, a German literary translator, renowned for his translations into German from contemporary authors, among others A.L. Kennedy, Aravind Adiga, Alan Bennett, John Griesemer, Nick Hornby or Rick Moody. Thus, the Romanian texts are re-translations from German. No matter how inspiring the losses or gains by this retranslation method may seem, such a research topic exceeds the scope of the present study, but it will certainly be the subject matter of a further article.

Due to the large array of topics, Fletcher's practical guide may, to a certain extent (or at least, at a first view), be sensed as chaotic; yet it actually illustrates the idea of diversity in unity - the miscellaneous traits or stereotypes of a so-called Germanness. Out of the fifty topics, many of them read as delicate, such as:

\footnotetext{
${ }^{3}$ For further reading, see Janine Albrecht's article on Herzke and his translating experiences, "Sprache ist wichtiger als Handlung" [Language is more important than the plot], available at https://www.dw.com/de/sprache-ist-wichtiger-als-handlung/a-6060129 (30.09.2010).
} 

$\begin{array}{ll}\checkmark & \text { the Third Reich Fever (Topic 44); } \\ \checkmark & \text { the keen nostalgia after the GDR (Topic 5); } \\ \checkmark & \text { the "hate/indifference triangle" (Topic 15) - Germany, }\end{array}$ Switzerland and Austria;

the poker face as representative for the German nation (Topic 1) - Topic 29),

pessimism ("Germany is very much a glass half empty nation"

politics, patriotism, bureaucracy or the Scandinavian superiority (Topic 33), to which some further German obsessions may be added: the microwave, cash, mould or wood fixations.

At the same time, rather safer issues (yet many of them sprinkled with ironic comments) are approached, for example: Christmas and Christmas fairs, Oktoberfest, flirting, the first day of school, weather, coffee and cake, mustard, pharmacies, renting and moving, contracts, grammatical gender ("the giant banana skin upon which everyone keeps slipping" - Topic 41) and word-origins, which Germans deeply respect (Topic 42).

The five translations rendered below discuss upon eclectic topics, such as the facial expressions of the Germans, their fondness for brevity, cash and Christmastime, as well as their constant failure in flirting. An English expat in Berlin, the author voices, in a witty manner, several stereotypes associated with the German people. Using the first-person narrative and permanently addressing an imaginary 'dear foreigner' or 'little Ausländer', representative of all expats in Germany, Fletcher succeeds in describing a rather thorny reality with a lot of humour and understanding.

The translation process per se went rather smoothly, yet it was frequently discontinued by the alternative versions of the translators. No wonder, since " $[\mathrm{t}]$ ranslation is a partly objective and partly subjective (and unconscious) process involving a series of decisions relating to the structure of dimensions in texts" (Jakobsen 1994: 40). When a rather dialectal word was chosen (half of the team was familiar with the southern/ Bucharest dialect, the other half with the Transylvanian one), it would be eventually replaced by a neutral, standard-language word:

e.g. Rom. Mare lucru. [Big thing/ deal.]/ Mare scofală*. (informal) [Big deal.]/ Mare brânză̈. (slang) [Big cheese/ deal.]/ Nimic nou. [Nothing new.]/ Germ. Große Sache./ Engl. Big deal ${ }^{5}$. (Topic 2)

Rom. După ce un an intreg [After ... the whole year]

\footnotetext{
${ }^{4}$ Being a bilingual guide (thus always two pages as one reference), I thought it would be more accurate to mention the number of the topic rather than the pages.

5 All the variants in italics explaining the examples in the book are taken as such from Fletcher's English original version. The English translations in square brackets represent a word-for-word/ literal rendering of their Romanian counterparts.
} 
te-ai străduit [you have striven]/

ți-ai dat silința [you have done your best]/

te-ai strofocat* (informal/ dialectal) [you have laid yourself out]/

te-ai trudit* (slightly informal, mostly ironical) [you have worked tooth and nail]/ yourself]/

te-ai frământat* (partially accurate/ understated) [you have fretted

te-ai zbătut* (overstated) [you have ripped along] să te integrezi [to integrate yourself].../

Germ. Nachdem du dich ein ganzes hartes Jahr mit Integrieren abgemüht hast/ Engl. After a hard year spent trying to fit in ... (Topic 16)

In order to retain cohesion, sentence/ textual homogeneity, stylistic beauty and the very essence of Romanianness, we have also appealed to various strategies, among others:

$\checkmark \quad$ tense/ verb correspondence: Oare cum am putea să punem in aceeași oală 80 de milioane de oameni? Chiar n-am putea! [How could we ever place 80 million people in the same pot? We could never!], instead of Chiar nu merge așa! [It doesn't work like that!]/ Germ. Wie kann man achtzig Millionen Menschen so über einen Kamm scheren? Geht gar nicht!! Engl. To typecast eighty million people like that? Never. (Topic 1);

avoidance of the double Genitive (present only in the German version, not in the English one), sensed as too pretentious for this informal type of text: la fel ca viațal cea a celorlalti locuitori ai acestei planete [like the life of all the other inhabitants of this planet], stylistically changed into ... de pe această planetă [on this planet]/ Germ. wie das aller anderen Bewohner dieses Planeten/ Engl. as anyone else on the planet (Topic 1);

$\checkmark \quad$ avoidance of redundant expressions, alliterations and repetitions:

- să-și exprime mai puțin propriile emoții [to express less their own emotions] was changed into the non-pleonastic să-și exprime mai puțin trăirile [to express less their emotions]/ Germ. es sich ins Gesicht zu schreiben/ Engl. to show it via their faces (Topic 1), besides avoiding the reiterance, in two consecutive lines, of emoții [emotions] and emotional [emotional];

- instead of the alliterative la fel ca cea a celorlalți [like that of all the other inhabitants], la fel ca viața celorlalți [like the life of all the other inhabitants]/ Germ. wie das aller anderen Bewohner/ Engl. as anyone else (Topic 1); nu doar despre expresiile faciale [not just about facial expressions] was eventually replaced with $n u$ doar despre mimicăl Germ. nicht nur ums Mienenspiel/ Engl. not just about the face (Topic 2);

- in order to avoid the repetition of the verb a incepe (to begin): $S \breve{a}$ începem. În Germania, Crăciunul începe la 1 decembrie./ Germ. Los geht's 
... Die deutsche Weihnacht beginnt am 1. Dezember./ Engl. Let's begin. German Christmas starts on December $1^{\text {st }}$. (Topic 16), the following variant was selected: Să-i dăm drumul atunci [Let's get going then].

preservation of English terms, only when necessary (due to a double presence in the text), as an illustration of the actual trend in the contemporary everyday Romanian language: un telefon de ultimă generație [a latest-generation telephone] is closely followed in the translation by un smartphone, or cash, as a lexical alternative to the much employed Romanian term, numerar (Topic 21);

$\checkmark \quad$ insertion of connectors: Pentru că nemții sunt ca bomboanele Smarties [Because Germans are like the Smarties candies]/ Germ. Deutsche sind wie Smarties/ Engl. To be German is to be an M\&M (Topic 1); nu e doar familie + capitalism, ci înseamnă ritualuri [not just family + capitalism, but it also implies rituals]/ Germ. Es ist nicht blo $\beta$... . Es gibt Rituale/ Engl. not just family + capitalism. There are rituals (Topic 16); De pildă, prietena mea, Annett [For example, my girlfriend...]/ Germ. Meine Freundin .../ Engl. My girlfriend, Annett (Topic 16). Although German and English prefer the short, clear-cut sentences, the cohesion being internally achieved, at the level of ideas, rather than by means of linking words, the Romanian language is characterized by rather long sentences, as well as by intrasentential and extrasentential connectors;

$\checkmark \quad$ ulterior completions in order to achieve Romanianness, by means of intensifiers: exact/ chiarl tocmai (exactly), tot/ mai (still);

$\checkmark \quad$ divergent/ free translations:

- instead of Vai de mine!/ Vai(-vai!) [Alas!]/ Germ. Oh je./ Engl. Oh dear. (Topic 16) was preferred the neutral $O, n u$ ! [Oh, no!]:

- Abia ajunge. [It's hardly enough.]/ Asta chiar nu-i de ajuns! [This is far from being enough.]/ Abia este suficient. [It's hardly sufficient.]/ Momentan nu ești la nivelul așteptat. [You haven't reached the expected level yet.]/ Germ. Das wird kaum reichen./ Engl. That's not going to cut it. (Topic 16) were replaced by a more natural variant, Te faci de râs! [You'll be everyone's laughingstock!]

- ar zâmbi ... în stânga și-n dreapta [smiling to the left and to the right] turned to be the best alternative for Germ. einfach Gratislächeln verteilen würden/ Engl. giving smiles out (Topic 1). Thus, the word-for-word translations have been substituted with the respective expressive meanings, since the first variants were merely unhappy choices in the given context.

- the coins described as filthy/grimy (schmuddelig) in the German text, parallelled by the Romanian pejorative term soios/ slinos (hence too much emotionally laden), were eventually translated by the 'milder' extrem de murdare [extremely dirty]. Although in the superlative, it represents a more 
suitable adjective for a written text in Romanian, as well as a compromise between the German and the English versions (dirty, Topic 21).

At the same time, fixed expressions and idioms were naturally adapted to the target language (Romanian):

e.g. Germ. über einen Kamm scheren [to have one's hair cut by the same comb]/ Rom. a pune în aceeași oală [to place someone in the same pot as somebody else]/ to typecast (Topic 1).

Germ. In der Kürze liegt die Würze [rhyming idiom: brevity is the soul of wit]/ Rom. Vorba multă, sărăcia omului [idiom: too much speaking leads to poverty]/ Find the beauty in brevity (Topic 2).

Furthermore, Topic 16 challenged us with two cultural concepts: one absent from the Romanian background, namely McGeiz; the other one, still present, yet posing difficulties in being neutrally translated - your old pal St. Nick. The first dilemma was solved by keeping the original name McGeiz in the translation, explained by a footnote as a German non-food discounter. In this particular case, largely compelled by the circumstances, we adhered to the so-called 'abusive fidelity':

"[T] he translator seeks to reproduce those very features of the foreign text that 'abuse' or resist the prevailing forms and values in the receiving culture, thereby allowing the translator to be faithful to aspects of the source text, but still participate in effecting cultural change in the target language" (Venuti in Gentzler, 2001: 39).

In other terms, there occurs a clash between the devotion to the original text and the commitment to genuine communication in the target language:

"A translation also aims at the naturalness of expression, at comprehensibility and at avoiding translationese, but it is obvious that sometimes such considerations conflict with the aim of commensurateness with the original" (Jakobsen, 1994: 40).

At the same time, the international confectionery brand Smarties, already present in the Romanian mentality, did not need any further explanations, even if it was retained as such in the Romanian text. Interestingly enough, the German text employs the British name Smarties, whereas the original version uses the American M\&M brand. Although an Englishman himself, Fletcher favours the American over the British term, probably out of a personal taste for such candies or a strategy to address a wider audience worldwide. In addition, Fletcher's sprinkling his texts with italicized German words, even if such words do exist in English, may read as 
a humorous device, a lexical attempt to integrate himself (since integration is the leitmotif of his guide) in the German culture as well.

The second problem arose by the very name of St. Nicholas, reading in Romanian as the neutral Moș Nicolae [Old Nicholas] or the religious Sfântul Nicolae [Saint Nicholas]. We eventually agreed to retain the neutral meaning. Yet, your old pal St. Nick would translate, literally and informally, as prietenull tovarășul tău vechil de demult, Sfântul Nicu (the variant of Miculaș, influenced by the Hungarian language and suggested by one of the students, was a dialectal word, thus not suitable for our translation). Keeping such original wording in the Romanian text would automatically trigger, in the Romanians' collective consciousness, the embodiment of Nicolae Ceaușescu and his much loathed communist regime. The juxtaposition of tovarăş (meaning pal, but also comrade) and Nicu (the short form of Nicolae) or even the shorter, yet worsely connoted term Nea Nicu' [old Nick], actually used for Ceaușescu within family-circles, mostly in their illicit jokes, would have become a serious error, a proper stance of translationese, ignoring the Romanian national and social context. In the end, in order to avoid the repetition of dragul [dear] as well, in Moșu', dragul de el [dear Old Man], a better first variant, I changed it to the final Moșu' cel sfânt [saint Old Man].

\section{Topic $1^{6}$ : Pokerface/ Poker Face \\ Poker face (pp. 8-10)}

$\mathrm{N}$-aș fi crezut vreodată că nemții sunt mai puțin expresivi, în comparație cu alte naționalități. Oare cum am putea să punem în aceeași oală 80 de milioane de oameni? Chiar n-am putea. Nu-nu, niciodată! Exclus! Și totuși ... stați o clipă, să termin ... pe cât de dramatică, nemaipomenită și diversă este viața emoțională a germanilor (la urma urmei, la fel ca viața celorlalți locuitori de pe această planetă), pe atât constat că aceștia tind să-și exprime mai puțin trăirile. Dacă ar exista o expresie facială tipic nemțească, aceasta ar fi poker face - o mină reținută, care trădează cât mai puțin posibil. Dacă ochii sunt într-adevăr oglinda sufletului, atunci oglinzile nemților ar fi acoperite de la bun început.

$\mathrm{Nu}$ e ca și când nemţii nu ar zâmbi sau nu ar gesticula chiar deloc, atunci când e absolută nevoie să dea o explicație sau să își exprime vreun sentiment. Dar și aceste forme de exprimare nonverbală ar trebui să aibă un efect, atunci când sunt produse spontan. Dacă toți oamenii ar zâmbi pur și simplu, în stânga și-n dreapta, doar pentru faptul că au găsit un euro pe jos, mai sunt doar două zile până la weekend sau se gândesc la o persoană dragă

\footnotetext{
${ }^{6}$ Topic 1 approaches the poker face, an expressionless face, viewed as the main trait of Germanness. The German text is also accompanied by eight identical faces representing the ideas of happiness, sadness, indifference, disappointment, concern, joy, surprise and scorn, in contrast to the one different face, desperately illustrating the phrase: Kein Bier da./ No beer.
} 
lor, atunci întregul sistem de emoții s-ar destabiliza la nivel național! Dacă am începe să zâmbim de la prima ocazie, toți ceilalți s-ar simți obligați să ne întoarcă zâmbetul, iar lucrul acesta ar putea declanșa o hiperinflație emoțională. De altfel, am avut parte de destulă hiperinflație în țara asta, mulţumim! Am putea ajunge să ne asemănăm într-o oarecare măsură cu Italia, unde trebuie să faci pantomimă un sfert de oră, ca să îți câștigi pâinea. $\mathrm{Nu}$, așa nu merge. Pentru că nemții sunt ca bomboanele Smarties - tari pe dinafară, moi pe dinăuntru.

Pentru tine, dragul meu străin, care provii dintr-un mediu migrațional, aceasta ar putea fi, cu siguranță, o problemă. Vino-ți în fire, amice! Bineînțeles, viața este extraordinară aici, asta ai și vrea să ne arăți, ridicânduți puțin colțul gurii sau făcând ochii mari, în încercarea de a afișa expresia, unanim recunoscută, de bucurie, entuziasm și fericire! Dar lasă, mai bine pokerface!

\section{Annex 1.1 \\ GE}

Ich würde niemals behaupten, dass Deutsche weniger emotional sind als andere Nationalitäten. Wie kann man achtzig Millionen Menschen so über einen Kamm scheren? Geht gar nicht! Niemals. Absolut verboten. Allerdings ... nein, Augenblick, lasst mich doch ausreden ... das Gefühlsleben der Deutschen ist zwar ebenso dramatisch, fantastisch und abwechslungsreich wie das aller anderen Bewohner dieses Planeten, doch ich würde sagen, sie neigen weniger dazu, es sich ins Gesicht zu schreiben. Gäbe es ein deutsches Nationalgesicht, es wäre ein Pokerface - eine zurückhaltende Miene, die so wenig wie möglich verrät. Wenn die Augen tatsächlich das Fenster zur Seele sind, so wurden die deutschen Fenster von Anfang an mit Rollos ausgestattet.

Es ist nicht so, als würden die Deutschen überhaupt nicht lächeln oder gestikulieren, wenn sie vom Erklärungsbedürfnis oder einem Gefühl mitgerissen werden. Aber diese körperlichen Ausdrucksformen sollen, wenn sie denn mal aus dem Sack gelassen werden, auch Wirkung entfalten. Wenn alle Leute einfach Gratislächeln verteilen würden, nur weil sie einen Euro auf dem Boden gefunden haben oder es bloß noch zwei Tage bis zum Wochenende sind oder sie an einen geliebten Menschen denken - das könnte die ganze emotionale Volkswirtschaft schwächen! Womöglich fangen die Leute dann bei erstbester Gelegenheit an zu lächeln, und alle würden sich verpflichtet fühlen mitzumachen, und das könnte eine emotionale Hyperinflation auslösen. In diesem Land hat es wahrlich genug Hyperinflation gegeben, vielen Dank auch. Wir könnten zu einer Art Italien werden, wo man eine fünfzehnminütige Pantomime aufführen muss, um einen Laib Brot zu erwerben. Nein, so geht es nicht. Deutsche sind wie Smarties - außen hart glasiert, innen süß schmelzend.

Für dich mit deinem Migrationshintergrund, lieber foreigner, könnte das natürlich ein Problem darstellen. Reiß dich zusammen, Kumpel! Sicher, das Leben hier ist so toll und du würdest das gern zeigen, indem du die Mundwinkel ein bisschen nach oben 
ziehst oder die Augen aufreißt als allgemein anerkannter Ausdruck von Freude, Begeisterung und Glück, aber: Lass es, Pokerface.

\section{Annex 1.2}

\section{EN}

I would never say that Germans are less emotional than other nations. To typecast eighty million people like that? Never. Absolute no-go. However... now, wait, hear me out... while Germans have emotional lives just as dramatic, fantastic, and varied as anyone else on the planet, I would say that they're much less inclined to show it via their faces. The German Nationalgesicht, if there were such a thing, would be a poker face - a restrained expression that gives away as little as possible. If the eyes really are the windows to the soul, the German window comes equipped with Rollos.

It's not that Germans don't smile, or gesticulate with their hands when lost in explanation or emotion. They just want those physical expressions - when they do bring them out of the bag - to have an impact. If everyone just went around giving smiles out total kostenlos because they've found a euro on the ground, or it's only two days until the weekend, or they are thinking about a loved one - well, that could weaken the whole emotional economy! People might begin smiling at even the smallest provocation and everyone else would, in turn, be forced to keep up, and that could trigger Hyper Emotion Inflation. There's been more than enough hyper-inflation in this country already, thank you very much. We might become Italy, where buying a loaf of bread requires a fifteenminute-long mime performance. No, that won't do. To be German is to be an M\&M hard on the outside, soft in the middle.

Of course, all this might be a problem for you, what with your Migrationshintergrund. Rein it in, buddy! Because living here is awesome, you might be tempted to show that by turning your mouth up at the edges, or widening your eyes in a commonly accepted display of joy, wonder, and happiness. Don't, Poker Face.

\section{Topic $2^{7}$ : In der Kürze liegt die Würze/ Find the beauty in brevity Vorba multă, sărăcia omului (p. 10)}

Nu e vorba, în cazul de față, doar despre mimică. Dacă în unele culturi se obişnuiește ca fiecare propoziție și fiecare moment de liniște să fie urmate de vorbe goale, oamenii locului, adică nemții, și-au dat seama că în concizie se ascunde o anumită noblețe.

Doar pentru că ești într-un restaurant cu soțul sau soția, nu înseamnă că trebuie să vorbiți neapărat unul cu celălalt. Ce mai aveți să vă spuneți și nu vați spus deja? Tocmai. Nimic. Doar pentru că simţi ceva anume, nu trebuie să și împărtășești imediat acest lucru. Toată lumea simte. Mare lucru! Vezi un cunoscut prin curte? Nu începe vreo discuție banală despre vreme. Un simplu Bună ziua și atât. Dar este vorba chiar despre vecinul tău - şi ce? Nu aveți destule ocazii să tot vorbiţi?

\footnotetext{
${ }^{7}$ Topic 2 briefly discusses terseness, as a further main characteristic of the Germans.
} 
Deoarece cuvintele sunt prețioase, nu ar trebui să le devalorizăm prin fraze interminabile. Vorba dulce, scurt și la obiect, mult aduce! Când nu-ți ajunge timpul, atunci mai bine numai scurt și la obiect. În egală măsură, merg și vorbele tăioase, în caz că tocmai te întrebai. Încă ți-aș mai putea spune câte ceva, dar la ce bun? Mai bine să le păstrăm pentru noi și să ne bucurăm de frumusețea conciziei. Punct.

\section{Annex 2.1}

GE

Dabei geht es nicht nur ums Mienenspiel. Während man in manchen Kulturen immerzu jeden Satz und jede Stille mit fadem Geschnatter füllt, haben die Menschen hier erkannt, dass in der Kürze eine gewisse edle Schönheit liegt. Bloß weil du mit deinem Ehepartner im Restaurant sitzt, müsst ihr ja nicht miteinander reden. Was habt ihr schon zu sagen, was noch nicht gesagt wurde? Eben. Nichts. Bloß weil du ein Gefühl hast, musst du es ja nicht unbedingt gleich teilen. Gefühle hat jeder. Große Sache. Du siehst im Innenhof jemanden, den du kennst? Fang kein unbeholfenes Gespräch über das Wetter an. Einfach «Guten Tag», und weiter geht's. Dann ist es eben dein Wohnungsnachbar - ja und? Da hast du ja noch reichlich Gelegenheit für Gespräche, oder?

Weil Worte kostbar sind, sollte man sie nicht mit Satz-Moltofill entwerten. Kurz und süß ist wunderbar. Wenn die Zeit dafür nicht reicht, dann eben nur kurz. Kurz und sauer geht meistens auch, falls du das fragen wolltest. Ich könnte dir noch viel mehr erzählen, aber warum eigentlich? Halten wir inne und genießen gemeinsam die Schönheit der Kürze. Ende der Diskussion.

\section{Annex 2.2}

EN

Brevity is not just about the face. While some cultures might rush to fill their sentences and silences with inane chatter, here, people have realised that there is a certain noble beauty to brevity. Just because you're out with your Ehepartner in a restaurant doesn't mean you have to talk to each other. What have you to say that you've not already said? Exactly. Nothing. Just because you have had a feeling, it doesn't mean you should automatically feel a need to share it. Everyone has feelings. Big deal. See someone you know in the Hof? Don't have an awkward conversation about the weather. Just "Guten Tag" them and get on with your day. So what if they're your next-door neighbour? There will be plenty of other chances to talk to them then, won't there? You might have heard the English expression "loose lips sink ships." Here, it's more like "loose lips sink friendships."

Because words are precious, don't cheapen them with poly-sentence-filla. Short and sweet is fine. If there's not enough time for that, just go with short. Short and sour usually also works, in case you're wondering. I could say more, but really, why? Let's stop here and both enjoy the beauty of brevity. Ende der Diskussion. 


\section{Topic 16 ${ }^{8}$ : Die deutsche Weihnacht/ The German Christmas Crăciunul german (pp. 35-38)}

După ce un an întreg ți-ai dat silința să te integrezi, probabil că ai nevoie de o pauză, nu-i așa? Perfect. Am exact ceea ce îți trebuie, și anume Crăciunul german. Poate că ai avut deja mai multe experiențe de Crăciun internațional, care, în mare parte, presupune aceleași ingrediente de bază cadouri, Iisus, certuri în familie. Nu te entuziasma prea repede, dragul meu străin! Versiunea germană nu e mereu aceeași. Aici Crăciunul se ia în serios: nu e doar familie + capitalism, ci înseamnă ritualuri, obligații, tradiții și târguri anuale, printre care trebuie să te descurci cum poți. Și apropo, sunt o mulțime de târguri! Ești pregătit? Să-i dăm drumul atunci.

În Germania, Crăciunul începe la 1 decembrie. Mai exact, atunci ai voie să deschizi prima ușiță a calendarului tău de Advent. STAI! Ce ai, acolo, în mână? Un calendar obișnuit din comerț, cumpărat dintr-un $\mathrm{McGeiz}^{* 9} \mathrm{cu} 2$ euro? O, nu! $\mathrm{Cu}$ așa ceva te faci de râs! Ca să obții nota maximă pentru originalitate, ar fi indicat să-ți confecționezi singur calendarul de Advent - unul cu totul special, așa cum ți-au făcut și părinții tăi, când aveai vreo 4 ani. De pildă, prietena mea, Annett, are un astfel de calendar, pe care i-l dă mamei ei înapoi în fiecare an în ianuarie, așa încât ea să i-l poată reumple și retrimite la sfârșitul lui noiembrie. Ce drăguț, nu?

În prima duminică de Advent poți și să aprinzi - cu mare fast, deci poate nar strica să împrumuți de undeva și o trompetă - prima lumânare din coroniţa de Advent. Pe această coroniță se găsesc ori patru lumânări, ori una singură cu patru secțiuni. Lumânarea este aprinsă în fiecare săptămână și este lăsată să ardă până se topește și ajunge în dreptul marcajului corespunzător săptămânii. În cazul unor astfel de lumânări simple, este esențial să te lași distras de prima dată, preparând salata de cartofi sau verificând ultimele știri de pe Spiegel Online. Așa că uiți de lumânare, care arde de tot, și cu ea, întregul Advent, chiar pe 1 decembrie. Aceasta este o traditie la fel de importantă precum lumânarea în sine.

Următorul eveniment palpitant al sezonului german de Crăciun are loc pe 6 decembrie - Moș Nicolae. În această zi îți poți lăsa liniștit pantofii în fața ușii. Ştiu că asta și faci, de fapt, în fiecare noapte, și nu se întâmplă nimic, dar azi este diferit. Dacă ai fost cuminte, dragul meu străin, Moșu' cel sfânt o să-ți pună în pantofi o grămadă de dulciuri. Cât de tare poate fi asta?! Dar dacă nu te-ai integrat așa cum se cuvine - dacă, de exemplu, nu ți-ai repetat verbele neregulate sau ai uitat care sunt verbele cu particulă separabilă, atunci primești niște nuielușe sau un cărbune. Așa-s regulile, amice!

\footnotetext{
8 The rather long text was chosen as a perfect match to the Christmas atmosphere in Germany, the real spatiotemporal framework of its translation.

${ }^{9} \mathrm{McGeiz}$ - the name of the German non-food discounter (Geiz meaning stinginess) is retained as such in the translation, but it is literally explained by a footnote into Romanian as 'lanț german de magazine cu prețuri foarte mici'.
} 
În continuare, presupunând că între timp ai vizitat deja cel puțin trei târguri de Crăciun diferite (mai multe în cele ce urmează) și ai făcut cel puțin o porție de fursecuri, chiar poți să începi să te bucuri de primul tău Ajun german autentic! Te-ai entuziasmat deja? Așa și trebuie. De ce? Fiindcă acum îţi poți deschide cadourile de Crăciun. Cu o zi întreagă mai devreme ca peste tot în lume. Acum există o mică problemă de logistică, deoarece Moș Crăciun nu are nicio noapte la dispoziție pentru a împărți cadourile când toată lumea doarme. De aceea, în Ajun familia se adună mai devreme pentru a face o plimbare. Acest timp scurt îi permite Moșului să intre pe neașteptate și să pună toate cadourile sub brad. $\mathrm{Nu}$ o grămadă de cadouri, cum se face în țări megacapitaliste. Ci un număr rezonabil de cadouri alese cu grijă, în mod ideal, realizate din lemn.

Deschiderea cadourilor îti va provoca desigur, foame. Ce vei mânca în această zi de sărbatoare, cea mai sfântă dintre toate? Ce întrebare stupidă! Cu siguranță, salată de cartofi! Mâncarea cu adevărat tradițională. De ce mănâncă nemții în Ajun salată de cartofi? Există două posibilități. Teoria germană spune că acesta este un ritual din vremuri străvechi: ziua de dinainte de Crăciun, adică seara de Ajun, reprezenta o zi normală de muncă. Astfel, se pregătea un fel simplu de mâncare, ce se putea servi rapid seara. Conform celeilalte teorii - să o numim „Teoria Mea” - nemții mănâncă salată de cartofi, pentru că le place la nebunie!

După cum poate ați observat deja, încă nu l-am pomenit pe Grinch. Stați liniștiți, există și aici. Și nu fură numai cadourile sau toată sărbătoarea, ci, de multe ori, și zilele libere. Când prima sau a doua zi de Crăciun cad în weekend, nu primești nicio zi liberă în plus, deci luni trebuie să lucrezi din nou, de parcă ar fi fost un weekend perfect normal. Ce prostie! Nimic nu e normal la Crăciunul german. Dacă îi întrebi pe nemți, majoritatea ți-ar spune probabil că este cea mai frumoasă perioadă din an. Iar pentru asta, firește că există un alt motiv, despre care va trebui să vorbim acum - târgurile de Crăciun ...

\section{Annex 3.1 $1^{10}$}

EN

After a hard year spent trying to fit in, you probably need a break, right? Great. I've got just the thing. It's called German Christmas. You may already be experienced with International Christmas, which shares many basic commonalities - gifts, Jesus, family arguments. But do not relax, foreigner. For not everything in the German variety is the same. Here, Christmas is serious: not just family + capitalism. There are rituals, obligations, traditions, and markets to be navigated. Lots of markets. Ready? Let's begin ...

\footnotetext{
${ }^{10}$ The German version has been intentionally left out, its size exceeding the accepted length of the article.
} 
German Christmas starts on December $1^{\text {st }}$. Then you get to open the first door of your advent calendar. STOP. What's that in your hand? Is it a mass-produced advent calendar that you bought from McGeiz for $€ 2$ ? Oh dear. That's not going to cut it. For maximum authenticity points, your advent calendar should also be a DIY affair - a special family advent calendar that your parents made for you when you were four. My girlfriend, Annett, has such a calendar and returns it every January to her mum, who refills it and sends it back again at the end of November. It's adorable. The first Sunday in December also allows - with great ceremonial pomp (perhaps consider borrowing a trumpet) - the lighting of the first candle on your Adventskranz (wreath). These wreaths either hold four candles, or just one demarcated into four parts. You light it each week, and let it burn down the required amount. If you're going to have such a single candle, it's essential that you get distracted preparing Kartoffelsalat or browsing the latest news stories on Spiegel Online, and forget to blow it out, burning the whole advent on December $1^{\text {st }}$. It's as much a tradition as the candle itself.

The next exciting event in your German Christmas occurs on December $6^{\text {th }}-S t$. Nikolaus Day. On this day, you get to leave your shoes out. I know you leave your shoes out every night and you get nothing for that. Well, tonight, that changes. If you've been a good little Ausländer, your old pal St. Nick is going to fill that footwear with chocolate! How cool is that?! If you've been a bad integrator, however - not practicing your irregular verbs, or forgetting which are trennbar - you'll wake to twigs or coal. Them's the rules.

Next up - assuming you've attended at least three different Weihnachtsmärkte (more on those in the next step) and baked at least one round of Plätzchen (German Christmas cookies) - you can proceed to your first German Christmas Eve! Are you excited? You should be. Why? Well, firstly, you get to open your presents on Christmas Eve already. A full day before patient lands. This does present a slight logistical challenge, however, because there is no night for Santa to spend delivering everyone's presents while they sleep. Therefore, on Christmas Eve, in the early evening, get the family together and go for a walk. This short window of time is used skilfully by Santa to nip in and set all your gifts up under the tree. Not lots of gifts, like they would do in hypercapitalist countries. Just a small number of thoughtful presents, ideally made of wood.

Of course, opening all those presents is going to make you quite hungry. What will you eat on this holiest of holy days? Silly question: Kartoffelsalat, of course! The true national dish. Why do Germans eat potato salad on Christmas Eve? There are two theories. Their theory is that this ritual harks back to Christmas Eve being a day of work, so you prepare food in advance that you can eat quickly that evening. The alternate theory - let's call it "My Theory" - is that they eat potato salad because they love potato salad.

No mention of the Grinch, you might have noticed. Worry not, he is alive and well in the stingy holiday allocation you receive. If der Erste and der Zweite Weihnachtsfeiertag fall on a weekend, you get no extra days off and have to go back to work on the Monday, as if it had been just another stinknormales weekend. Bah, humbug. Because there's nothing normal about a German Christmas. In fact, if you asked people, most would probably say it's the best time of the whole year. There's 
another reason for this, of course, a reason we have to talk about now Weihnachtsmärkte...

\section{Topic 21: König Bargeld/ Cash is King \\ Regele Numerar (pp. 46-47)}

Reținerea germanilor, când vine vorba de plastic, nu se oprește la jucării. Aceasta se referă și la cardurile (plastifiate) din portofel. După cum probabil ai constatat deja, aici domnește numerarul, iar tronul său este făcut din bancnote mototolite și monede extrem de murdare. În ciuda tuturor încercărilor, este puțin probabil ca Regele Numerar să fie detronat și decapitat în urma unei revoluții a cardurilor de credit.

Teama de aceste carduri și de datele conținute de ele este atât de mare aici, încât $80 \%$ din tranzacțiile de zi cu zi se fac în bani cash. Aceasta are, firește, de-a face cu istoria aparte a Germaniei. În trecut, statul și-a dovedit abilitățile remarcabile în ceea ce privește controlul cetățenilor. Dacă oricum ai într-un buzunar măruntiș, iar în celălalt, un telefon de ultimă generație, nu prea are sens să îti faci griji dacă ești supravegheat sau nu: smartphone-ul este dispozitivul perfect de supraveghere, inventat vreodată. Este ca un agent de securitate, mai este jurnal, cel mai bun prieten și, totodată, detector portabil de minciuni. Însă e mai mult decât atât, nu-i așa?

I-am întrebat pe prietenii mei germani care e motivul pentru care mai toți nemții sunt obsedați de cash; mi-au răspuns că nu e vorba de a fi supravegheat, ci de a te auto-supraveghea. Unul dintre ei s-a exprimat în felul următor:

- Vreau să-mi monitorizez fiecare cheltuială în parte. În cazul cardurilor de credit, e ca și cum ai avea bani de jucărie, înțelegi? Nu te afectează când $\hat{\imath} i$ cheltui, pentru că nu sunt reali. Atunci când pentru un espresso și un covrig plătesc efectiv 6.20 euro, asta ar trebui să mă afecteze.

Deci iată și răspunsul! Nu e vorba că te controlează altcineva, e mai degrabă despre autocontrol și despre masochism fiscal.

\section{Annex 4.1}

\section{$\boldsymbol{G E}$}

Die Scheu der Deutschen vor Plastik endet nicht beim Spielzeug. Sie betrifft auch die Plastikkarten in ihren Brieftaschen. Wie du wahrscheinlich schon bemerkt hast, regiert hier das Bargeld, und sein Thron ist aus zerknitterten Scheinen und schmuddeligen Metallmünzen gebaut. Trotz allen Absichtserklärungen ist auch nicht so bald damit zu rechnen, dass König Bargeld von einer Kreditkartenrevolution gestürzt und enthauptet wird.

Die Angst vor diesen Karten und ihren Daten sitzt hier so tief, dass $80 \%$ der alltäglichen Geldgeschäfte in bar abgewickelt werden. Das hat natürlich ein bisschen mit Deutschlands einzigartiger Geschichte zu tun. Der Staat hat in der Vergangenheit herausragende Fähigkeiten in Bürgerkontrolle bewiesen. Wenn man allerdings in der einen Hosentasche Kleingeld, in der anderen ein Smartphone 
stecken hat, ist es relativ sinnlos, sich Sorgen wegen Überwachung zu machen: Das Smartphone ist das vollkommenste Überwachungsgerät, das je ersonnen wurde. Es ist Stasi, Tagebuch, bester Freund und tragbarer Lügendetektor in einem. Es muss also noch etwas anderes dahinter stecken, richtig?

Ich habe deutsche Freunde nach der landestypischen Bargeldbesessenheit befragt, und sie haben mir verraten, dass es nicht nur darum geht, sich nicht überwachen zu lassen, sondern auch darum, sich selbst zu überwachen. Einer von ihnen formulierte es so: «Ich möchte jede Ausgabe spüren. Bei Kreditkarten ist es irgendwie bloß Spielgeld, verstehst du? Es tut nicht weh, weil es nicht echt ist. Wenn ich für einen Espresso und einen Bagel 6 Euro 20 bezahle, dann soll es wehtun, das Geld wegzugeben.» Da haben wir also die Antwort. Es geht nicht um Fremd-, sondern um Selbstkontrolle - und um fiskalischen Masochismus.

\section{Annex 4.2}

\section{EN}

The German distrust of plastic doesn't stop at toys. It also concerns the plastic in their wallets. As you've probably noticed by now, cash is king here, and it sits proudly atop a throne of paper bills and dirty metal coins. It's a king not likely to be beheaded any time soon in an Amex- or Visa-led revolution.

Such is the fear of cards that fully $80 \%$ of all the country's daily transactions are in cash. Of course, this has a little bit to do with Germany's unique history. It has demonstrated, historically, an aptitude for citizen Überwachung (surveillance). However, when the other pocket of your jeans holds a smartphone, it's pointless to worry about being tracked. Smartphones are the most perfect surveillance device ever designed. They're the Stasi, your diary, your best friend, and a portable lie detector, all in one. So there must be something else going on here as well, right?

I've asked German friends about the national cash obsession and they tell me it's not just about not being tracked but also about them tracking themselves. As one said, "I want to feel every transaction. With cards, it's all just funny money, you know? It doesn't hurt because it's not real. When I by an espresso and a bagel for $€ 6.20$, it should hurt to hand that money over." So, there we have the answer. It's about tracking, not being tracked - and fiscal masochism.

\section{Topic 37: Beim Flirten versagen/ Fail at Flirting \\ Când flirtul eșuează (p. 72-73)}

Sper că aveai deja o relație când te-ai mutat în Germania, căci să începi una aici poate fi o adevărată provocare - în primul rând, deși cetățenii acestei frumoase țări sunt, într-adevăr, competenți în multe domenii, la flirt nu se pricep mai deloc. Ce-i drept, ei știu de unde provine acest lucru - este ceva asemănător cu obiceiul câinilor în parc, atunci când se adulmecă unul pe altul, doar că mai subtil și folosindu-se de cuvinte, poate puțin și de limbajul corpului, pentru a merge la sigur. Dar în ce constau aceste cuvinte și acest limbaj al corpului?

NU EXISTĂ NICIO REGULĂ! Tocmai aici e problema.

În ceea ce privește flirtul, subtextul este cel puțin la fel de important ca şi comunicarea în sine. Din moment ce în societatea germană se evită 
folosirea subtextului în $99 \%$ din cazuri, în restul de 1\%, când este, totuși, permis - situațiile romantice -, lipsa de experiență iși spune cuvântul. Până când cei din cadrul Institutului German de Standardizare vor elabora, în sfârșit, un tabel de flirt, cu metodele de abordare recomandate, tot vor mai exista confuzii, eșecuri sau situații jenante.

Bărbații se tem să facă ei primul pas, crescuți fiind de generații de nemțoaice puternice și independente, iar acum nu vor să le răpească independența și autonomia femeilor de care sunt interesaţi. Acestea din urmă compensează prin faptul că sunt, adeseori, șocant de directe. Paul, un prieten irlandez, mi-a povestit cum și-a adunat odată tot curajul, pentru a aborda, într-un final, o nemțoaică blondă și frumoasă, care stătea la bar. S-a apropiat emoționat de ea și tocmai voia să își facă intrarea cu o replică amuzantă, pe care o repetase în drum spre ea.

- Imi pare rău, dar ești prea scund, i-a spus ea, înainte ca el să apuce să termine jumătate din propoziție.

Și i-a întors spatele. Asta a fost tot.

Măcar s-a scuzat.

\section{Annex 5.1}

$\boldsymbol{G E}$

Ich hoffe, du hast schon in einer Beziehung gelebt, als du nach Deutschland gezogen bist, denn hier eine anzufangen, kann eine echte Herausforderung sein - vor allem, weil die Bürger dieses schönen Landes zwar in vielen Bereichen kompetent, beim Flirten jedoch eher unbedarft sind. Sie wissen zwar, worum es grundsätzlich geht es ist so ähnlich wie das, was Hunde im Park machen, wenn sie einander am Hinterteil schnüffeln, nur subtiler und mit Worten, vielleicht auch noch mit ein bisschen Körpersprache, um sicherzugehen. Aber was für Worte und welche Körpersprache?

ES GIBT KEINE REGELN! Darin liegt das Problem.

Beim Flirten ist der Subtext mindestens ebenso wichtig wie der gesprochene Text. Aber da in der deutschen Gesellschaft zu 99\% der Zeit jeder Subtext vermieden wird, fehlt es beim entscheidenden Prozent - also bei der Romantik - komplett an Erfahrung damit. Bis die Leute vom DIN endlich eine Flirttabelle mit empfohlenen Vorgehensweisen erstellen, wird es noch eine Menge Verwirrung, Missgeschicke und Plumpheiten geben.

Männer fürchten sich davor, den ersten Schritt zu machen, weil sie von Generationen starker, unabhängiger deutscher Frauen erzogen wurden und die Frau ihres Interesses nun nicht ihrer Unabhängigkeit und Autonomie berauben wollen. Frauen überkompensieren das, indem sie oftmals erschreckend direkt sind. Paul, ein irischer Freund von mir, hat mir erzählt, wie er einmal allen Mut zusammennahm, um endlich eine schöne blonde Deutsche anzusprechen, die an der Bar stand. Nervös ging er auf sie zu und setzte zu einem witzigen Eröffnungsspruch an, den er auf dem Weg zu ihr geübt hatte. «Entschuldige, aber du bist zu klein», sagte sie, noch bevor er halb durch war mit seinem Satz. Dann drehte sie sich zur Theke um. Ende der Diskussion. 
Immerhin hat sie sich entschuldigt.

\section{Annex 5.2}

\section{EN}

Hopefully you were already in a relationship before you moved to Germany, because finding one here can have its challenges - the biggest challenge being that the citizens of this fine land, while competent in many areas, tend to be rather unskilled at flirting. They get the basic premise - it's like what dogs do in the park to each other's behinds, only more subtle and with words, or maybe a bit of body language thrown in for good measure. But which words and what body language?

THERE ARE NO RULES! Therein lies the problem.

Flirting is as much about sub-text as actual text. But since German society shuns sub-text $99 \%$ of the time, in the $1 \%$ where it is allowed - romance - no one has any experience using it. Until the DIN people create a best-practice Flirttabelle, there are going to be a lot of accidents, confusion, and heavy handedness.

Men are afraid to make the first move, since they've been raised by generations of strong, independent German women and so don't want to rob the girl of her independence and autonomy. Women overcompensate for that and are, sometimes, scarily direct. An Irish friend, Paul, tells a story about finally plucking up the courage to approach a beautiful blonde German woman standing at the bar. Nervously, he approached and began delivering the funny opening line he'd been rehearsing on the walk over. "I'm sorry, you're too short," she said before he'd gotten halfway through it. Then she turned back to the bar. Ende der Diskussion.

Still, at least she said sorry.

As a final remark, the Romanian texts provided in the present article represent translations, an outcome that usually raises eyebrows and questions about the originality of such writings and the authorship of the translators. Nevertheless, one should bear in mind that an ideal translation needs to approach the source-text anew, in terms of the target-language lexis and grammar, semantics and pragmatics. In Jakobsen's words,

"Though translation always involves producing a target text that will uniquely match only one other text interlingually, the information processing that this involves in expert human translation takes place at the same cognitive level as ordinary text production. Therefore, translation is as complicated and as multifaceted as text production" (Jakobsen, 1994: 48).

In addition, according to Lawrence Venuti, an American translation studies scholar,

"[E]very act of translation [is] transformative and creative, seldom transparent, invariably interpretive. Translations are complex texts full of multiple intertextual connotations and allusions, containing 
multiple discourses and linguistic materials, giving translators various choices to support or resist predominant literary and ideological views" (in Gentzler, 2001: 38).

Whether or not have the present translations into Romanian managed to be creative and authentic, freed of translationese fingerprints, still remains an open question, as well as a future goal; in fact, any text is prone to further alterations, observations and improvements. The main objective of the current study has actually been to demonstrate the various difficulties, be they on lexical, semantic or cultural levels, one encounters throughout any process of translating, mostly in reference to literary translations. On the other hand, from the translators' perspective, it has certainly been a pleasure to work with some of the satirical excerpts in How to be German. Not only due to the topics Fletcher's guide approaches in a candid manner, as if analyzing the series of frustrations foreigners typically experience in Germany (the author included), but mainly due to all the various linguistic challenges we faced on the border between a Romance and a Germanic language.

\section{References:}

Baker, M. (1992). In Other Words. A Coursebook on Translation. London and New York: Routledge. https://doi.org/10.4324/9780203133590

Chesterman, A. (2016). Memes of Translation. The Spread of Ideas in Translation Theory. Amsterdam/ Philadelphia: John Benjamins Publishing Company. https://doi.org/10.1075/btl.123

Gentzler, E. (2001). Contemporary Translation Theories. Second Revised Edition. Clevedon: Multilingual Matters Ltd.

Jakobsen, A.L. (1994). “Towards a Definition of Translation Types". In Jakobsen, Arnt Lykke (Ed.). Translating LSP Texts: Some Theoretical Considerations (pp. 33 56). Frederiksberg: Samfundslitteratur.

Korzen, I.; Gylling, M. (2012). Text Structure in a Contrastive and Translational Perspective. On Information Density and Clause Linkage in Italian and Danish. Translation: Computation, Corpora, Cognition (TC3), Vol. 2, No. 1, July 2012, 23-46. Mainz: Johannes-Gutenberg-Universität.

Landers, C.E. (2001). Literary Translation. A Practical Guide. Clevedon: Multilingual Matters Ltd. https://doi.org/10.21832/9781853595639

Stolze, R. (1994). Übersetzungstheorien: eine Einführung/ Translation Theories: an Introductory Guide. Tübingen: Gunter Narr Verlag.

* Fletcher, A. (2016). How to be German in 50 new steps/ Wie man Deutscher wird. In 50 neuen Schritten. München: C.H. Beck. 